\title{
A Study on the Accuracy of Prediction in Recommendation System Based on Similarity Measures
}

\author{
Nadia Fadhil AL-Bakri ${ }^{*}$ \\ Soukaena Hassan Hashim² \\ Received 24/4/2018, Accepted 16/10/2018, Published 17/3/2019 \\ This work is licensed under a Creative Commons Attribution 4.0 International License.
}

\begin{abstract}
:
Recommender Systems are tools to understand the huge amount of data available in the internet world. Collaborative filtering (CF) is one of the most knowledge discovery methods used positively in recommendation system. Memory collaborative filtering emphasizes on using facts about present users to predict new things for the target user. Similarity measures are the core operations in collaborative filtering and the prediction accuracy is mostly dependent on similarity calculations. In this study, a combination of weighted parameters and traditional similarity measures are conducted to calculate relationship among users over Movie Lens data set rating matrix. The advantages and disadvantages of each measure are spotted. From the study, a new measure is proposed from the combination of measures to cope with the global meaning of data set ratings. After conducting the experimental results, it is shown that the proposed measure achieves major objectives that maximize the accuracy Predictions.
\end{abstract}

Key words: Collaborative Filtering, Inverse User Frequency, Prediction, Recommender System, Similarity Measure.

\section{Introduction:}

Recommender systems are tools that utilize the beliefs of a group of users to assist entities in that group to effectively explore new things of interest from a possibly tremendous set of choices. Collaborative Filtering (CF) is being developed for generating recommendations. $\mathrm{CF}$ can be categorized into two main algorithms: memory-based and model-based. Memory-based algorithms use the whole user-item database to generate predictions. Similarity measures are employed to find user's neighborhood.

Memory collaborative filtering can be classified mainly into user to user based and item to item based filtering. User-based exploits the relationship between the target user and all other users. Item-based makes use of the similarity between two items. Similarity measure computation depends mostly on user's explicit ratings (users scan items and rate them on a rating scale values). Although explicit rating captures user favorites to items perfectly, its main drawback is sparsity problem due to the vast amount of information in the world (1).

\footnotetext{
Department of Computer Science, AL Nahrain University, Baghdad, Iraq.

2 Department of Computer Science, University of Technology, Baghdad, Iraq.

*Corresponding author: nfi@sc.nahrainuniv.edu.iq
}

In this paper, a study is presented to analyze the results of prediction values with the use of different similarity measures.

In section 2, challenges of collaborative filtering techniques are presented. In section 3, the Related Works on this field are subjected. In section 4 , most similarity measures used in $\mathrm{CF}$ are presented in a table form. In section 5, the Experimental Results are conducted. The last section is the conclusion of this study.

\section{Challenges of Collaborative Filtering Techniques}

A brief introduction to the challenges that are considered important for the development of the research on recommender systems is introduced:

1- Cold-start problem: This refers to a situation where a recommender does not have adequate information about a user or an item in order to make relevant predictions. This is one of the major problems that reduce the performance of recommendation system.(2)

2- Data sparsity problem: This problem occurs as a result of lack of enough information, that is, when only a few of the total number of items available in a database are rated by users. This always leads to a sparse user item matrix, inability to locate 
successful neighbors and, finally, the generation of weak recommendations.(2)

3- Scalability: This is a problem associated with recommendation algorithms because computation normally grows linearly with the number of users and items. It is crucial to apply recommendation techniques which are capable of scaling up in a successful manner as the number of dataset in a database increases.(2)

4- Synonymy: Synonymy is the tendency of very similar items to have different names or entries. Most recommender systems find it difficult to make distinction between closely related items.(2)

5- Gray Sheep: This refers to the users whose opinions do not consistently agree or disagree with any group of people and thus do not benefit from collaborative filtering.(3)

6- Shilling Attacks: It is the case where anyone can provide recommendations; people may give tons of positive recommendations for their own materials and negative recommendations for their competitors.(3)

7- The Long Tail problem: It is composed of a small number of popular items, the well-known hits, and the rest are located in the heavy tail, those do not sell that well. The Long Tail offers the possibility to explore and discover-using automatic tools; such as (recommenders or personalized filters) vast amounts of data.(4)

8- Diversity: In the recommendation process, the user should be presented with a range of options and not with a homogeneous set of alternatives.(4)

\section{Related Work}

In what follows, some of the previous research literatures related to the techniques used in userbased collaborative filtering is presented with employing different data sets. The related works are shown in Table (1).

Table 1. Different Collaborative Filtering Approaches Used in Previous Works with their References

\begin{tabular}{|c|c|c|c|c|c|}
\hline $\begin{array}{l}\text { Ref. } \\
\text { No. }\end{array}$ & $\begin{array}{c}\text { Authors \& } \\
\text { Publication Year }\end{array}$ & $\begin{array}{l}\text { Approach } \\
\text { Used }\end{array}$ & $\begin{array}{l}\text { Methods And Tools } \\
\text { Used }\end{array}$ & $\begin{array}{l}\text { Dataset } \\
\text { Used }\end{array}$ & $\begin{array}{l}\text { Problem } \\
\text { To Solve }\end{array}$ \\
\hline (1) & $\begin{array}{l}\text { Abdelwahab, A } \\
\text { Et Al. } \\
\mathbf{2 0 0 9}\end{array}$ & $\begin{array}{l}\text { User-Based And Item- } \\
\text { Based Collaborative } \\
\text { Filtering }\end{array}$ & $\begin{array}{c}\text { User-Based And Item-Based } \\
\text { Collaborative Filtering }+ \text { Spectral } \\
\text { Clustering }\end{array}$ & $\begin{array}{l}\text { MovieLens } \\
100 \mathrm{~K} \\
\text { Book- } \\
\text { Crossing }\end{array}$ & Sparsity \\
\hline (5) & $\begin{array}{c}\text { KG, S., \& } \\
\text { Sadasivam,G.S. } \\
\mathbf{2 0 1 7}\end{array}$ & $\begin{array}{c}\text { Memory Based } \\
\text { Collaborative Filtering }\end{array}$ & $\begin{array}{l}\text { Modified Similarity Model } \\
\text { Jaccard Measure +PSS } \\
\text { (Proximity-Significance- } \\
\text { Singularity)+Bhattacharya }\end{array}$ & $\begin{array}{c}\text { News } \\
\text { Jester } \\
\text { Datasets }\end{array}$ & Sparsity \\
\hline (6) & $\begin{array}{l}\text { Huang, B. H., \& } \\
\text { Dai B. R., } \\
\mathbf{2 0 1 5}\end{array}$ & Collaborative Filtering & $\begin{array}{l}\text { Weighted Distance Model(WD)\& } \\
\text { Jacaard Measure }\end{array}$ & $\begin{array}{l}\text { MovieLens } \\
100 \mathrm{~K} \\
\text { MovieLlens } \\
1 \mathrm{M}\end{array}$ & $\begin{array}{l}\text { Prediction } \\
\text { Accuracy }\end{array}$ \\
\hline (7) & $\begin{array}{l}\text { Wu, Z., } \\
\text { Et Al. } 2014\end{array}$ & Collaborative Filtering & $\begin{array}{l}\text { Modified Similarity and Fuzzy } \\
\text { Clustering }\end{array}$ & $\begin{array}{l}\text { MovieLens } \\
100 \mathrm{~K}\end{array}$ & $\begin{array}{l}\text { Sparsity } \\
\text { Real-Time } \\
\text { Response } \\
\text { Speed }\end{array}$ \\
\hline$(8)$ & $\begin{array}{l}\text { Katukuri, J., } \\
\text { Et Al. } \\
\mathbf{2 0 1 4}\end{array}$ & Similarity Measure & $\begin{array}{l}\text { Clustering Using Hadoop Map } \\
\text { Reduce }\end{array}$ & $\begin{array}{l}\text { Ebay.Com } \\
\text { Site }\end{array}$ & Scalability \\
\hline (9) & $\begin{array}{l}\text { Mao, J., } \\
\text { Et Al. } \\
\mathbf{2 0 1 3}\end{array}$ & $\begin{array}{c}\text { Memory Based } \\
\text { Collaborative Filtering }\end{array}$ & $\begin{array}{l}\text { Modified Pearson Correlation } \\
\text { Measure By Similarity Impact } \\
\text { Factor. }\end{array}$ & $\begin{array}{l}\text { MovieLens } \\
100 \mathrm{k}\end{array}$ & Sparsity \\
\hline (10) & $\begin{array}{l}\text { Anad D. \& } \\
\text { Bharadwaj K. } \\
\text { 2011 }\end{array}$ & $\begin{array}{l}\text { Collaborative } \\
\text { Filtering \& } \\
\text { Evolutionary }\end{array}$ & $\begin{array}{l}\text { Automatic Learning Of Weights By } \\
\text { Genetic Used In Sparsity Measures }\end{array}$ & $\begin{array}{l}\text { MovieLens } \\
\text { Jester } \\
\text { Datasets }\end{array}$ & Sparsity \\
\hline (11) & $\begin{array}{l}\text { Lee, H.C } \\
\text { Et Al. } \\
\mathbf{2 0 0 7}\end{array}$ & $\begin{array}{l}\text { Collaborative Filtering } \\
\text { and Content-Based } \\
\text { Filtering }\end{array}$ & $\begin{array}{l}\text { Neighborhood Based Collaborative } \\
\text { Filtering Algorithm (NBCFA). } \\
\text { Correspondence Mean } \\
\text { Algorithm(CMA) }\end{array}$ & $\begin{array}{l}\text { MovieLens } \\
100 \mathrm{k} \\
\text { Movielens } \\
1 \mathrm{M}\end{array}$ & $\begin{array}{l}\text { Prediction } \\
\text { Accuracy }\end{array}$ \\
\hline (12) & $\begin{array}{l}\text { Lee, } \mathrm{S}, \\
\text { Et AI. } \\
\mathbf{2 0 0 4}\end{array}$ & Collaborative Filtering & Discovery Hidden Similarity(DHS) & $\begin{array}{l}\text { MovieLlens } \\
\quad 100 \mathrm{k}\end{array}$ & $\begin{array}{l}\text { Sparsity } \\
\text { Scalability }\end{array}$ \\
\hline
\end{tabular}

\section{Collaborative Filtering Algorithm}

The recommender system can be abstracted as a black box to generate suggestions for users. It is constructed from the following steps: (13)

\section{1- Representation of raw data}

Specific data about users can be collected in explicit or implicit ways. The data in this paper is taken explicitly from the MovieLens data set. Then this 
data set is represented in the form of the UserMovie rating matrix to be further processed.

\section{2- Similarity Computation}

It is the most essential stage in the recommendation system because the accuracy of the prediction process is dependent on this stage. It determines the $\mathrm{K}$-nearest users to the active user. The $\mathrm{K}$ users form the neighborhood for the target user. Different similarity measures are depicted in Tables $(2,3)$.

Table 2. different similarity measures with their specification and disadvantages (5) (14) (15)

\begin{tabular}{|c|c|c|c|c|}
\hline Eq.no & $\begin{array}{c}\text { Similarity } \\
\text { Measure }\end{array}$ & Similarity Measure Formula & Specification & Disadvantage \\
\hline \multirow[t]{2}{*}{1} & \multirow[t]{2}{*}{$\begin{array}{l}\text { Cosine } \\
(\mathrm{COS})\end{array}$} & $\begin{array}{l}\operatorname{SIM}(u, v)^{\cos } \\
=\operatorname{cosine}\left(\overline{R_{u}}, \overline{R_{v}}\right) \\
\quad=\frac{\overline{R_{u}} \cdot \overline{R_{v}}}{\left\|R_{u}\right\|\left\|R_{v}\right\|} \\
=\frac{\sum_{i=1}^{N} R_{u, i} \times R_{v, i}}{=}\end{array}$ & \multirow{2}{*}{$\begin{array}{l}\text { Measures the angle } \\
\text { between } \mathrm{u} \text { and } \mathrm{v} \text { vectors. } \\
\text { If angle equals } 0 \text { then } \\
\text { cosine Simi- } \\
\text { larity }=1 \text { and they } \\
\text { are similar. } \\
\text { if equals } 90 \text { then } \\
\text { cosine similarity } \\
=0 \text { and they are not } \\
\text { similar. }\end{array}$} & \multirow[t]{2}{*}{$\begin{array}{l}\text { Cosine similarity does } \\
\text { not account for the } \\
\text { preference of the user's } \\
\text { rating. }\end{array}$} \\
\hline & & $\sqrt{\sum_{i=1}^{N}\left(R_{u, i}\right)^{2}} \sqrt{\sum_{i=1}^{N}\left(R_{v, i}\right)^{2}}$ & & \\
\hline 2 & $\begin{array}{l}\text { Pearson } \\
\text { correlation } \\
\text { coefficient } \\
\quad(\mathrm{PCC})\end{array}$ & $\begin{array}{l}S I M(u, v)^{p c c} \\
=\frac{\sum_{i \in I}\left(R_{u, i}-\overline{R_{u}}\right)\left(R_{v, i}-\overline{R_{V}}\right)}{\sqrt{\sum_{i \in I}\left(R_{u, i}-\overline{R_{u}}\right)^{2}} \sqrt{\sum_{i \in I}\left(R_{v, i}-\overline{R_{V}}\right)^{2}}}\end{array}$ & $\begin{array}{l}\text { The Pearson correlation } \\
\text { coefficient takes values } \\
\text { from }+1 \text { (strong positive } \\
\text { correlation) to }-1 \text { (strong } \\
\text { negative correlation). } \\
\text { The Pearson algorithm } \\
\text { makes use of negative } \\
\text { correlations as well as } \\
\text { positive correlations to } \\
\text { make predictions. }\end{array}$ & $\begin{array}{l}\text { The Pearson correlation } \\
\text { measurement not } \\
\text { consider the fact of } \\
\text { finding similar users } \\
\text { for common items have } \\
\text { less influence in } \\
\text { recommendation } \\
\text { process than finding } \\
\text { similar users on un } \\
\text { common items. }\end{array}$ \\
\hline 3 & $\begin{array}{l}\text { Constrained } \\
\text { Pearson } \\
\text { correlation } \\
\text { coefficient } \\
\text { (CPCC) }\end{array}$ & $\begin{array}{l}\operatorname{SIM}(\boldsymbol{u}, \boldsymbol{v})^{c p c c} \\
=\frac{\sum_{i \in I}\left(\boldsymbol{R}_{u, i}-\boldsymbol{R}_{M e d}\right)\left(\boldsymbol{R}_{v, i}-\boldsymbol{R}_{\text {Med }}\right)}{\sqrt{\sum_{i \in I}\left(\boldsymbol{R}_{u, i}-\boldsymbol{R}_{M e d}\right)^{2}} \sqrt{\sum_{i \in I}\left(\boldsymbol{R}_{v, i}-\boldsymbol{R}_{M e d}\right)^{2}}}\end{array}$ & $\begin{array}{l}\text { Does not make use of } \\
\text { negative "correlations" } \\
\text { as the Pearson algorithm } \\
\text { does. It uses median } \\
\text { value instead of average } \\
\text { rating. }\end{array}$ & $\begin{array}{l}\text { Does not take into } \\
\text { account the number of } \\
\text { common rating. }\end{array}$ \\
\hline 4 & $\begin{array}{l}\text { Jaccard } \\
\text { Distance }\end{array}$ & $\begin{array}{c}\boldsymbol{S I M}(\boldsymbol{u}, \boldsymbol{v})^{\text {jaccard }}=\frac{\left|\boldsymbol{I}_{U}\right| \cap\left|I_{V}\right|}{\left|I_{U}\right| \cup\left|I_{V}\right|} \\
\text { Where }\left|I_{U}\right|\left|I_{V}\right| \text { is the total number of items rated by } \\
\text { u and v respectively. } \\
\text { Jaccard distance=1-Sim }(u, v)^{\text {jaccard }}\end{array}$ & $\begin{array}{l}\text { The concept behind this } \\
\text { measure is that users are } \\
\text { more similar if they have } \\
\text { more common ratings. }\end{array}$ & $\begin{array}{l}\text { Jaccard coefficient } \\
\text { does not consider the } \\
\text { absolute ratings. }\end{array}$ \\
\hline 5 & $\begin{array}{l}\text { Inverse User } \\
\text { Frequency } \\
\text { (IUF) }\end{array}$ & $\begin{array}{r}I U F_{i} \text { is the significance of the item } i \text { in the similarity } \\
\text { computation } \\
i \text { is for specific item } \\
N \text { is no. of users } \\
n_{i} \text { is the no. of co-rated users for item } i\end{array}$ & $\begin{array}{l}\text { Formula decreases the } \\
\text { weight on common } \\
\text { items, because these } \\
\text { items are less beneficial } \\
\text { in recommendation } \\
\text { process to target users. }\end{array}$ & $\begin{array}{l}\text { Does not take into } \\
\text { account the number of } \\
\text { common rating. }\end{array}$ \\
\hline
\end{tabular}

In Table (3), additional similarity measures are defined as a combination of the previous similarity measures mentioned. 
Table 3. Additional Similarity Measures from Previously Mentioned Measures [source: "own elaboration"]

\begin{tabular}{|c|c|c|c|c|}
\hline Eq.no & $\begin{array}{c}\text { Similarity } \\
\text { Measure }\end{array}$ & Similarity Measure Formula & Specification & Disadvantage \\
\hline \multirow[b]{2}{*}{6} & $\begin{array}{c}\text { Constrainted } \\
\text { pearson }\end{array}$ & $\begin{array}{l}\operatorname{SIM}(u, v)^{c p c c \& I U F} \\
=\frac{\sum_{i=1}^{N} f_{i}^{2}\left(R_{u, i}-R_{M e d}\right)\left(R_{v, i}-R_{M e d}\right)}{}\end{array}$ & \multirow{2}{*}{$\begin{array}{l}\text { Take the effect of } \\
\text { positive and negative } \\
\text { similarity values and } \\
\text { give weight to less } \\
\text { known items. }\end{array}$} & \multirow{2}{*}{$\begin{array}{c}\text { Does not make } \\
\text { use of negative } \\
\text { correlations and } \\
\text { number of } \\
\text { common rating is } \\
\text { not counted. }\end{array}$} \\
\hline & $\begin{array}{l}\text { correlation } \\
\text { with IUF }\end{array}$ & $\sqrt{\sum_{i=1}^{N} f_{i}^{2}\left(R_{u, i}-R_{M e d}\right)^{2}} \sqrt{\sum_{i=1}^{N} f_{i}^{2}\left(R_{v, i}-R_{M e d}\right)^{2}}$ & & \\
\hline 7 & $\begin{array}{c}\text { Constrainted } \\
\text { pearson } \\
\text { correlation } \\
\text { with jaccard }\end{array}$ & $S I M=S I M^{C P C C} * S I M^{J A C C A R D}$ & $\begin{array}{l}\text { Take the effect of } \\
\text { positive and negative } \\
\text { similarity values and } \\
\text { consider the number of } \\
\text { common rating. }\end{array}$ & $\begin{array}{l}\text { Does not give } \\
\text { weight to less } \\
\text { known item. }\end{array}$ \\
\hline 8 & $\begin{array}{l}\text { Constrained } \\
\text { Pearson } \\
\text { correlation } \\
\text { with IUF \& } \\
\text { Jaccard }\end{array}$ & SIM $^{\text {proposed }}=$ SIM $^{\text {CPCC\&IUF }} *$ SIM $^{\text {JACCARD }}$ & $\begin{array}{l}\text { 1-Take the effect of } \\
\text { positive and negative } \\
\text { similarity values. } \\
\text { 2- Consider the number } \\
\text { of common rating. } \\
\text { 3- Give weight to less } \\
\text { known items (long tail } \\
\text { problem. }\end{array}$ & $\begin{array}{l}\text { Does not cope } \\
\text { with Synonymy } \\
\text { and gray sheep } \\
\text { problems. }\end{array}$ \\
\hline
\end{tabular}

\section{3- Prediction Computation}

After a similarity computation, a group of size K of nearest neighbors for the target user is chosen. Then a prediction for the target user (a) on a target item (i) is generated by aggregating weighted ratings of neighbor users (u's) plus the mean of target users' rating $\left(\overline{\boldsymbol{R}_{\boldsymbol{a}}}\right)$. The prediction formula for user-based collaborative filtering is shown below (15):

predict $($ user $a$, item $i)=$

$\overline{R_{a}}+\frac{\sum_{u \in U} \operatorname{sim}(a, u) \cdot\left(R_{u, i}-\overline{r_{u}}\right)}{\sum_{u \in U}|\operatorname{sim}(a, u)|} \ldots . .$. EQ. 9

Where $u \in U$ are target user's neighbors (K highest similarities).

Sim (a,u) similarity between target user (a) and neighbor users (u's).

$R_{u, i}$ rating of user $u$ to item $i$.

\section{Results and Discussion:}

In this section, the impact of the similarity measures on the prediction formula for user-based collaborative filtering is tested. The task is to assess different similarity measures mentioned in Table (2) and Table (3) by applying them on Movielens data set which contains 943 users, 1682 movies and 100,000 ratings (provided by GroupLens Research) (16. The rating scale of this data set is [1 to 5].

Using MATLAB as a programming language, MovieLens data set is loaded and represented as User-Movie matrix where the rows represent the number of users and the columns are the number of movies. In this study, a sample of the experiments is taken to clear the idea more simply and also do not take a lot of area in the page. Table
(4) shows an adjacency matrix, containing number of co-rated (common) movies between five users.

These values are needed in the prediction formula, which specify the number of movies shared among users Tables from (5 to 12) below their sources are "own elaboration".

Table 4. The number of co-rated movies between users.

\begin{tabular}{llllll}
\hline & User1 & User2 & User3 & User4 & User5 \\
\hline User1 & 262 & 15 & 7 & 4 & 73 \\
User2 & 15 & 52 & 8 & 3 & 3 \\
User3 & 7 & 8 & 44 & 6 & 1 \\
User4 & 4 & 3 & 6 & 14 & 1 \\
User5 & 73 & 3 & 1 & 1 & 165 \\
\hline
\end{tabular}

Similarity measures formulas mentioned in Table (2) and Table (3) are applied on User-Movie matrix, the obtained adjacency similarity matrices are shown in Tables (5 to 11) for five users.

Table 5. Pearson Similarity Measure

\begin{tabular}{cccccc}
\hline & User1 & User2 & User3 & User4 & User5 \\
\hline User1 & 1.0000 & 0.9545 & 0.8555 & 0.9318 & 0.9285 \\
User2 & 0.9545 & 1.0000 & 0.9522 & 0.9918 & 0.9829 \\
User3 & 0.8555 & 0.9522 & 1.0000 & 0.9484 & 1.0000 \\
User4 & 0.9318 & 0.9918 & 0.9484 & 1.0000 & 1.0000 \\
User5 & 0.9285 & 0.9829 & 1.0000 & 1.0000 & 1.0000 \\
\hline
\end{tabular}

Table 6. Cosine Similarity Measure

\begin{tabular}{lccccc}
\hline & User1 & User2 & User3 & User4 & User5 \\
\hline User1 & 0.0000 & 0.1468 & 0.0507 & 0.0513 & 0.3648 \\
User2 & 0.1468 & 0.0000 & 0.1258 & 0.1177 & 0.0494 \\
User3 & 0.0507 & 0.1258 & 0.0000 & 0.2367 & 0.0234 \\
User4 & 0.0513 & 0.1177 & 0.2367 & 0.0000 & 0.0131 \\
User5 & 0.3648 & 0.0494 & 0.0234 & 0.0131 & 0.0000 \\
\hline
\end{tabular}


Table 7. Constraint Similarity Measure

\begin{tabular}{cccccc}
\hline & User1 & User2 & User3 & User4 & User5 \\
\hline User1 & 1.000 & 0.632 & -0.105 & 0.309 & 0.465 \\
User2 & 0.632 & 1.000 & -0.674 & 0.816 & 0.866 \\
User3 & -0.105 & -0.674 & 1.000 & -0.195 & 1.000 \\
User4 & 0.309 & 0.816 & -0.195 & 1.000 & $\mathrm{NaN}$ \\
User5 & 0.465 & 0.866 & 1.000 & $\mathrm{NaN}$ & 1.000 \\
\hline
\end{tabular}

Table 8. Jaccard Similarity Measure

\begin{tabular}{cccccc}
\hline & User1 & User2 & User3 & User4 & User5 \\
\hline User1 & 0 & 0.9498 & 0.9766 & 0.9853 & 0.7938 \\
User2 & 0.9498 & 0 & 0.9091 & 0.9524 & 0.9860 \\
User3 & 0.9766 & 0.9091 & 0 & 0.8846 & 0.9952 \\
User4 & 0.9853 & 0.9524 & 0.8846 & 0 & 0.9944 \\
User5 & 0.7938 & 0.9860 & 0.9952 & 0.9944 & 0 \\
\hline
\end{tabular}

Table (9) Constrained Pearson Correlation with Jaccard

\begin{tabular}{llllll}
\hline & User1 & User2 & User3 & User4 & User5 \\
\hline User1 & 0 & 0.600 & -0.10 & 0.304 & 0.369 \\
User2 & 0.600 & 0 & -0.61 & 0.777 & 0.853 \\
User3 & -0.10 & -0.61 & 0 & -0.17 & 0.995 \\
User4 & 0.304 & 0.777 & -0.17 & 0 & $\mathrm{NaN}$ \\
User5 & 0.369 & 0.853 & 0.995 & $\mathrm{NaN}$ & 0 \\
\hline
\end{tabular}

Table 10. Constrained Pearson Correlation with IUF

\begin{tabular}{llllll}
\hline & User1 & User2 & User3 & User4 & User5 \\
\hline User1 & 1.000 & 0.805 & -0.46 & 0.702 & 0.490 \\
User2 & 0.805 & 1.000 & -0.84 & 0.963 & 0.929 \\
User3 & -0.46 & -0.84 & 1.000 & 0.371 & 1.000 \\
User4 & 0.702 & 0.963 & 0.371 & 1.000 & $\mathrm{NaN}$ \\
User5 & 0.490 & 0.929 & 1.000 & $\mathrm{NaN}$ & 1.000 \\
\hline
\end{tabular}

Table 11. Constrained Pearson Correlation with IUF \& Jaccard Similarity Measure

\begin{tabular}{llllll}
\hline & User1 & User2 & User3 & User4 & User5 \\
\hline User1 & 0.000 & 0.765 & -0.453 & 0.692 & 0.390 \\
User2 & 0.765 & 0.000 & -0.766 & 0.918 & 0.916 \\
User3 & -0.453 & -0.766 & 0.000 & 0.329 & 0.995 \\
User4 & 0.692 & 0.918 & 0.329 & 0.000 & $\mathrm{NaN}$ \\
User5 & 0.390 & 0.916 & 0.995 & $\mathrm{NaN}$ & 0.000 \\
\hline
\end{tabular}

Then the prediction formula (EQ.9) is applied, using the resultant similarity matrices on selected users; to generate predictions for their rated and unrated movies. Prediction for rated movies is used to see how accurate the generated results to the real rating. Prediction results are shown in Table (12) for User 1, User 2, User 4 and User 5.

Table 12. Prediction Computation Results

\begin{tabular}{|c|c|c|c|c|c|c|c|c|c|}
\hline \multirow[t]{2}{*}{$\begin{array}{c}\text { Similarity } \\
\text { measures }\end{array}$} & \multicolumn{4}{|c|}{$\begin{array}{l}\text { User } 1 \text { prediction } \\
\text { to: }\end{array}$} & \multicolumn{2}{|c|}{$\begin{array}{l}\text { User2 prediction } \\
\text { to: }\end{array}$} & \multirow{2}{*}{$\begin{array}{c}\begin{array}{c}\text { User4 } \\
\text { predicti } \\
\text { on to: }\end{array} \\
\text { Movie } \\
\text { ID.11 }\end{array}$} & \multicolumn{2}{|c|}{$\begin{array}{c}\text { User } 5 \\
\text { Prediction } \\
\text { to: }\end{array}$} \\
\hline & $\begin{array}{c}\text { Movie } \\
\text { ID.2 }\end{array}$ & $\begin{array}{l}\text { Movie } \\
\text { ID. } 3\end{array}$ & $\begin{array}{c}\text { Movie } \\
\text { ID. } 4\end{array}$ & $\begin{array}{l}\text { Movie } \\
\text { ID. } 5\end{array}$ & $\begin{array}{l}\text { Movie } \\
\text { ID. } 1\end{array}$ & $\begin{array}{l}\text { Movie } \\
\text { ID. } 10\end{array}$ & & $\begin{array}{l}\text { Movie } \\
\text { ID.42 }\end{array}$ & $\begin{array}{l}\text { Movie } \\
\text { ID.63 }\end{array}$ \\
\hline $\begin{array}{l}\text { Pearson } \\
\text { Correlation }\end{array}$ & $3.03 \cong 3$ & $3.53 \cong 4$ & $3.64 \cong 4$ & $3.30 \cong 3$ & $4.09 \cong 4$ & $3.84 \cong 4$ & $4.49 \cong 5$ & $3.12 \cong 3$ & $2.52 \cong 3$ \\
\hline $\begin{array}{c}\text { Cosine } \\
\text { correlation } \\
\text { measure } \\
\text { Constraint }\end{array}$ & $3.33 \cong 3$ & $3.07 \cong 3$ & $3.95 \cong 4$ & $3.21 \cong 3$ & $4.39 \cong 4$ & $4.02 \cong 4$ & $4.75 \cong 5$ & $3.14 \simeq 3$ & $2.49 \cong 3$ \\
\hline $\begin{array}{c}\text { Correlation } \\
\text { coefficient } \\
\text { Jaccard }\end{array}$ & $2.99 \cong 3$ & $3.62 \cong 4$ & $2.75 \cong 3$ & $3.03 \cong 3$ & $4.05 \cong 4$ & $3.92 \cong 4$ & $4.41 \cong 4$ & $3.06 \cong 3$ & $2.40 \cong 2$ \\
\hline $\begin{array}{l}\text { Distance } \\
\text { measure }\end{array}$ & $3.35 \cong 3$ & $3.35 \cong 3$ & $3.16 \cong 3$ & $3.36 \cong 3$ & $4.27 \cong 4$ & $4.03 \cong 4$ & $4.61 \cong 5$ & $3.03 \cong 3$ & $2.57 \cong 3$ \\
\hline $\begin{array}{c}\text { Constraint } \\
\text { correlation } \\
\text { with IUF }\end{array}$ & $3.37 \cong 3$ & $3.66 \cong 4$ & $2.61 \cong 3$ & $2.90 \cong 3$ & $3.62 \cong 4$ & $3.98 \cong 4$ & $4.43 \cong 4$ & $3.03 \cong 3$ & $2.43 \cong 2$ \\
\hline $\begin{array}{l}\text { Constraint } \\
\text { correlation } \\
\text { \&Jaccard } \\
\text { Constraint }\end{array}$ & $3.35 \cong 3$ & $3.61 \cong 4$ & $3.44 \cong 3$ & $3.11 \cong 3$ & $3.99 \cong 4$ & $3.89 \cong 4$ & $4.39 \cong 4$ & $3.03 \cong 3$ & $2.44 \cong 2$ \\
\hline $\begin{array}{l}\text { correlation } \\
\text { \& IUF }\end{array}$ & $3.36 \cong 3$ & $3.55 \cong 4$ & $3.34 \simeq 3$ & $3.06 \cong 3$ & $3.68 \cong 4$ & $2.42 \cong 2$ & $4.44 \cong 4$ & $4.60 \cong 5$ & $2.23 \cong 2$ \\
\hline Real rating & 3 & 4 & 3 & 3 & 4 & 2 & 0 & 5 & 0 \\
\hline
\end{tabular}

The discussion of the prediction computation results from Table (12) is presented below:

User 1 rated (3) to movie2 because all the prediction values according to different similarity measures approach (3) which is the same as the real rating (3) in MovieLens data set.

User 1 rated (4) to movie3 conducting 5 similarity measures which is the same as the real rating (4) in 
MovieLens data set and rated (3) using cosine and Jaccard measure.

User 1 rated (3) to movie4 using 5 similarity measures which is the same as the real rating (3) and rated (4) using Pearson correlation and cosine measures.

User 1 rated (3) to movie5 using all similarity measures which is the same values as in the real rating (3).

User 2 rated (4) for movie1 which is the same as in real rating (4)

User 2 rated (2) for movie10 using the proposed similarity measure Constrained Correlation with IUF and Jaccard only which is the same real rating (2) in movielens data set.

User 4 rated (4) for movie11 which is not rated by the user in the real Movielens data set.

User 5 rated 5 for movie42 when using the proposed similarity measure Constrained Correlation with IUF and Jaccard only which is rated 5 in real rating.

User 5 rated (2) for movie63 which is not rated by the user 5 in the real MovieLens data set.

\section{Conclusion:}

This study shows the explicit rating significance rather than just calculating distances among users using similarity measures. The aim is to focus on the global meanings of rating values in real data set rather than local meanings. Moreover less known movies are focused on by using the parameter (IUF) and treated effectively and as a result, the diversity is achieved and long tail problem can be partially solved. Many similarity measures are conducted, it is concluded that it is not possible to relate between users effectively, since it provides a relatively equivalent similarity values. But in the proposed similarity measure (Constrained Correlation with IUF and Jaccard); a relatively accurate prediction results are obtained because each user in the data set became distinguished as a dependable user since it provides different similarity values for each pair of users. It is concluded from this study that the explicit rating of users can be dependable in the prediction process for target users. Better results are obtained from a combination of similarity measures because the weakness of each of measure is strengthened by another measure.

\section{Conflicts of Interest: None.}

\section{Reference:}

1. Abdelwahab A, Sekiya H, Matsuba I, Horiuchi Y, Kuroiwa $\mathrm{S}$.Collaborative filtering based on an iterative prediction method to alleviate the sparsity problem. ACM, Proceedings of the 11th International
Conference on Information Integration and Webbased Applications \& Services [internet].2009 December; pp:

DOI:10.1145/1806338.1806406.

2. Isinkaye F, Folajimi Y, Ojokoh B .Recommendation systems: Principles, methods and evaluation. Egyptian Informatics Journal [internet]. 2015 November; 16(3):261-273. DOI:10.1016/j.eij.2015.06.005.

3. Su X, Khoshgoftaar T .A survey of collaborative filters techniques. Advances in artificial intelligence [internet].2009 August. DOI:10.1155/2009/421425.

4. Celma O .Music recommendation: In Music recommendation and discovery. Springer [internet]. 2010; 194 p. Berlin Heidelberg. DOI: 10.1007/978-3642-13287-2.

5. KG S, Sadasivam G S .Modified Heuristic Similarity Measure for Personalization using Collaborative Filtering Technique. Appl. Math. Inf. Sci. [internet].2017 November; 11(1):30715.DOI:10.18576/amis/110137.

6. Huang B H, Dai B R .A Weighted Distance Similarity Model to Improve the Accuracy of Collaborative Recommender System. $16^{\text {th }}$ IEEE International Conference on Mobile Data Management [internet].2015 September; pp: 104-109. DOI: 10.1109/MDM.2015.43.

7. $\mathrm{Wu} \mathrm{Z}$, Chen Y, Li T .Personalized recommendation based on the improved similarity and fuzzy clustering. Information Science, Electronics and Electrical Engineering (ISEEE) International Conference [internet].2014 April; Vol. 2, pp: 13531357. DOI:10.1109/InfoSEEE.2014.6947895.

8. Katukuri J, Könik T, Kolay S, Mukherjee R .Recommending similar items in large-scale online marketplaces. IEEE International Conference on Big Data [internet].2014; pp: 868-876. DOI: 10.1109/BigData.2014.7004317.

9. Mao J, Cui Z, Zhao P, Li X .An improved similarity measure method in collaborative filtering recommendation algorithm. IEEE, Cloud Computing and Big Data (CloudCom-Asia) International Conference [internet].2013 Dec.; pp: 297-. DOI:10.1109/CLOUDCOM-ASIA.2013.39.

10. Anand D, Bharadwaj K K .Utilizing various sparsity measures for enhancing accuracy of collaborative recommender systems based on local and global similarities. ALSEVIER, Expert systems with applications [internet].2011; 38(5):5101-5109. DOI: 10.1016/j.eswa.2010.09.141.

11. Lee H C, Lee S J, Chung Y J .A study on the improved collaborative filtering algorithm for recommender system. IEEE, Software Engineering Research, Management \& Applications 5th ACIS International Conference [internet].2007 Aug.; pp: 297-304. DOI:10.1109/SERA.2007.33.

12. Lee S, Yang J, Park S Y .Discovery of hidden similarity on collaborative filtering to overcome sparsity problem. Springer, International Conference on Discovery Science [internet] 2004 Berlin, Heidelberg; pp: 396-402. DOI: 10.1007/978-3-54030214-8_36. 
13. Verma A, Bhamidipati K .A survey of memory based methods for collaborative filtering based techniques for online Recommender systems. (IJCET) [Internet].2013; 4(2):366-372.

14. AL Bakri N F, Hashim S H .A modified similarity measure for improving accuracy of user-based collaborative filtering. Iraqi Journal of Science [internet].2018; 59(2B):934-945. DOI:10.24996/ijs.2018.59.2B.15.
15. Adomavicius G, Tuzhilin A .Toward the next generation of recommender systems: a survey of the state-of-the-art and possible extensions. IEEE Transaction, Knowledge Data Eng. [internet].2005; 17(6):734-749. DOI: 10.1109/TKDE.2005.99.

16. MovieLens data set. Available from: https://grouplens.org/datasets/movielens/.

\section{دراسة حول دقة التببؤ في نظام التوصية على أسـاس مقاييس التشابه سكينه حسن هاثم2 ناديه فاضل البكري

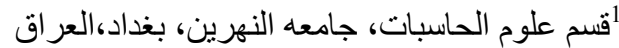

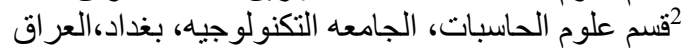

نظم التوصية هي أدوات لفهم الكم الهائل من البيانات المتاحة في عالم الإنترنت. التصفية التعاونية هي واحدة من أكثر تقنيات اكتشاف المعرفة المستخدمة بشكل إيجابي في نظام التوصيات. نركز التصفية التعاونية القائمة على الذاكرة على التى استخدام الحقائق حول

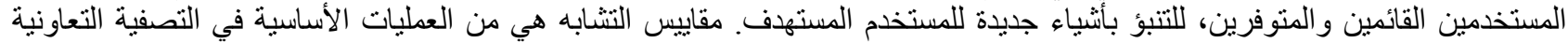

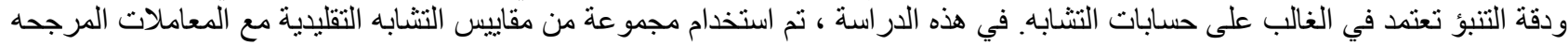

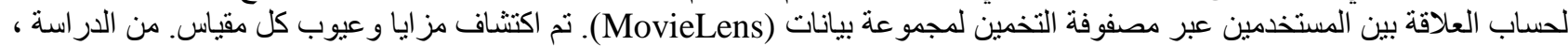

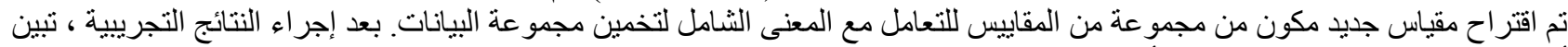

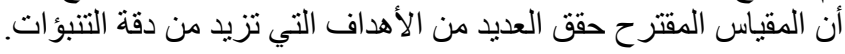
الكلمات المفتاحية: التصفية التعاونية ،معكوس تردد المستخدم ،التتبؤ ،نظام التوصية، قياس التشابه . 